\title{
Development and validation of instrument for assessing practical skills in fault diagnoses and repairs of radio and television systems in Nigerian technical colleges
}

\author{
${ }^{1 *}$ Okwelle, P. Chijioke (Ph.D.) and ${ }^{2}$ Prof. Okeke Benchuks (Ph.D.) \\ ${ }^{1}$ Department of Science and Technical Education, Rivers State University of Science and \\ Technology, Port Harcourt, Nigeria \\ ${ }^{2}$ Department of Vocational Education, Nnamdi Azikiwe University, Awka, Nigeria \\ ${ }^{*}$ Corresponding Author: pc_okwelle@yahoo.com, +2348023311193
}

\begin{abstract}
This study developed and validated a radio and television skill assessment scale (RTSAS) that will improve the assessment of students' performance in diagnoses and repairs of faults in radio and television systems. The study answered one research question and tested two hypotheses. The RTSAS comprising of practical skills based on National Business and Technical Examinations Board (NABTEB) curriculum and related literature were developed and validated by seven experts. Radio and television teachers from technical colleges in the South-South zone of Nigeria were the sample used for item validation of the RTSAS which was further tried out on radio and television students. Data collected were analyzed using statistical mean, Cronbach's Alpha and One Way Analysis of Variance (ANOVA). The result of the study showed that six clusters and 76 practical skills were found appropriate for the RTSAS. Also, the instrument was found to possess a high reliability of 0.95 . Based on this result, it was recommended amongst others that radio and television teachers in technical colleges and other similar institutions in Nigeria should be made to be aware and learn to use the RTSAS for assessing performance in radio and television fault diagnoses and repairs.
\end{abstract}

Keywords: Development; Validation; Assessment; Practical skill; Radio and Television.

\section{INTRODUCTION}

The quality of learning outcome demonstrated by students of a training programme will determine the extent to which behavioural or instructional objectives have been achieved (Okwelle, 2011). A simplistic measure of quality of teaching will be how effectively and efficiently students can, at the end of a course or programme of study, apply or use the skills that have been learned (Mansell, 2002). In the field of technical and vocational education, practical skill activities form major part of instruction and assessment. Padelford (1984) described practical skills as organized and coordinated forms of physically observable activities exhibited in the process of carrying out tasks in vocational and technical education and other related fields. Thus, performance tests which require examinees to perform a task instead of answering questions (Khan, 2007), are regarded by many as the most credible tool for assessment of practical skill assessment. Performance tests require students to demonstrate practical skills and operations taught and to perform adequately under conditions that are similar to the working conditions of the trade (Olatain and Ali, 1997).

Performance testing method may be either in form of process evaluation, product evaluation or some combination of both (Okeke, 2004; Wolansky, 1988). Process assessment requires attentive and consistent teacher observation and rating of student performance; while product or outcome assessment involves the teacher objectively judging the quality of the finished product. This implies that performance test involves assessing how students are working as well as the completed task or product. Both process and product assessment are accomplished by the teacher through the development of some type of observational techniques such as checklists, rating scale and recording sheet to be used for rating the students' performances (Ojoko, 2000).

In Nigerian educational system, technical colleges offer technical and vocational education programmes for the purpose of producing middle level skilled manpower required for the nation's economic and technological 
development (Federal Republic of Nigeria [FRN], 2004). Radio and television system is one of the engineering trades incorporated into the technical college curriculum to achieve this national goal. National Technical Certificate (NTC) is awarded by the National Business and Technical Examinations Board (NABTEB) to students who have completed their post- primary education at technical colleges (NABTEB, 2004). The NTC radio and television trade curriculum among others is aimed at training skilled technical manpower equipped with the necessary technical knowledge and practical skills for diagnosing and repairing faults in radio and television systems. These tasks are to be carried out by students step by step before arriving at final stage of accomplishing the task. Consequently, each step and the final stage or finished product is to be assessed comprehensively and systematically by the teacher, if the objective of the training is to be achieved.

Evidence from research studies (Bukar, 2006; Chejile, 2006; Garba, 1993; Okwelle, 2003) indicate that the popular method of assessing students' practical skills in technical and vocational education programmes including Radio and Television trade by their teachers and instructors in Nigerian technical colleges is based on mere looking at the students' finished products with little or no attention to the process involved in carrying out the practical work. Marks are then awarded to the students based on what the teacher or examiner feels the student deserves. This observatory method of awarding marks to students is considered biased and subsumes the award of grades that show individual examiner's feelings. According to Chejile (2006) the reason for this lopsided practice of assessment by the teachers could be that they are either reluctant or too busy to assess the various stages of individual student's work by at least preparing a definite procedure of assessment. However, NABTEB uses a marking scheme checklist, to assess students' performance in practical components of NTC examinations. This scheme merely highlights the major skills to be rated but lacking in details, the various stages of specific skills involved in the process of carrying out the task given. The implication of this is that the scores and grades assigned to students in practical works by the teachers may not be true representative of their performances.

In order to improve the standard of assessment in technical and vocational education, there is need to use valid and reliable assessment instruments which will take account of the process of practical activities leading to the completion of the final practical products. Though such instruments have been developed in some other technical and vocational trades (Bukar, 1995, 2006; Chiejile, 2006; Garba, 1993; Okeke, 2004; Yalams, 2005), literature available to the researcher indicate that no such instrument has been developed and validated for use in assessing practical skills in radio and television trade in Nigerian technical colleges. Against the background of paucity of standard instrument for assessing practical skills in Radio and Television trade prompted this study.

The purpose of this study therefore, was to develop and validate an instrument for assessing students' practical skills in diagnosing and repairs of faults in Radio and television systems at technical college level. Specifically, the study attempted to identify appropriate practical skills for inclusion in a Radio and Television Skill Assessment Scale (RTSAS) instrument for use in technical colleges. Secondly, was to ascertain if there were differences among technical teachers on their ratings of appropriate practical skills for inclusion in the RTSAS based on their qualifications and length of years of experience.

Research Question: The following research question guided the study:

1. What practical skills are considered appropriate for inclusion in Radio and Television Skill Assessment Scale (RTSAS) for assessing students' practical skills in fault diagnoses and repairs of radio and television systems?

Hypotheses: The following null hypotheses were tested at five percent level of significance.

1. There are no significant differences among three groups of trained technical teachers (FTC/TTC/ NCE; B.Sc./HND/PGDTE; M.Sc./PhD), regarding the appropriateness of practical skills for inclusion in radio and television skill assessment scale (RTSAS) ( $P$ $<0.05$ ).

2. There are no significant differences among three groups of experienced technical teachers (below 5 years; $5-10$ years and above 10 years); regarding the appropriateness of practical skills for inclusion in radio and television skill assessment scale (RTSAS) $(\mathrm{P}<$ 0.05).

\section{MATERIALS AND METHODS}

The study is an instrumentation research. Instrumentation design is appropriate for use when introducing new procedures, technologies or instrument for educational practices (Gay, 1996). The area of the study was South-South zone of Nigeria comprising, Akwa Ibom, Bayelsa, Cross River, Delta, Edo and Rivers States. There were two target populations in this study. These included 41 teachers and 287 final year students identified from the department of Radio and Television in all the 20 technical colleges accredited by National Board for Technical Education (NBTE), to run 
NABTEB programme with specialization in Radio, Television and Electronics Works in the South-South Zone of Nigeria. The entire 41 Radio and television teachers were used in the study for the purpose of validating the RTSAS. No sampling was done because the number was small and manageable. The validators (raters) were made up of technical teachers with three groups of highest qualifications namely: 11 teachers with FTC/TTC/NCE; 22 teachers with B.Sc /HND/ PGDE; and eight teachers with M.Sc / PhD. Also, 17 of the 41 teachers had below five years teaching experience, 14 teachers had five to ten years teaching experience while 10 teachers had experiences above 10 years.

Also as part of the sample, a total of 38 final year students of the department of radio and television were purposively sampled from two of the 20 colleges. The choice of these two schools was based on the adequacy of all the models of equipment, materials and tools necessary for implementing the test. This sample was used for try-out of the validated RTSAS instrument for the purpose of ascertaining its initial reliability.

The instrument developed in this study is "Radio and Television Skill Assessment Scale" (RTSAS). Based on the suggestions of Benson and Clark (1982); Cluzeau (2002); Orion et al (1996); Samarakkoddy et al (2010); Wiersma and Jurs (1990), the procedure adapted in the development of the RTSAS was a multi-staged approach shown in figure 1.

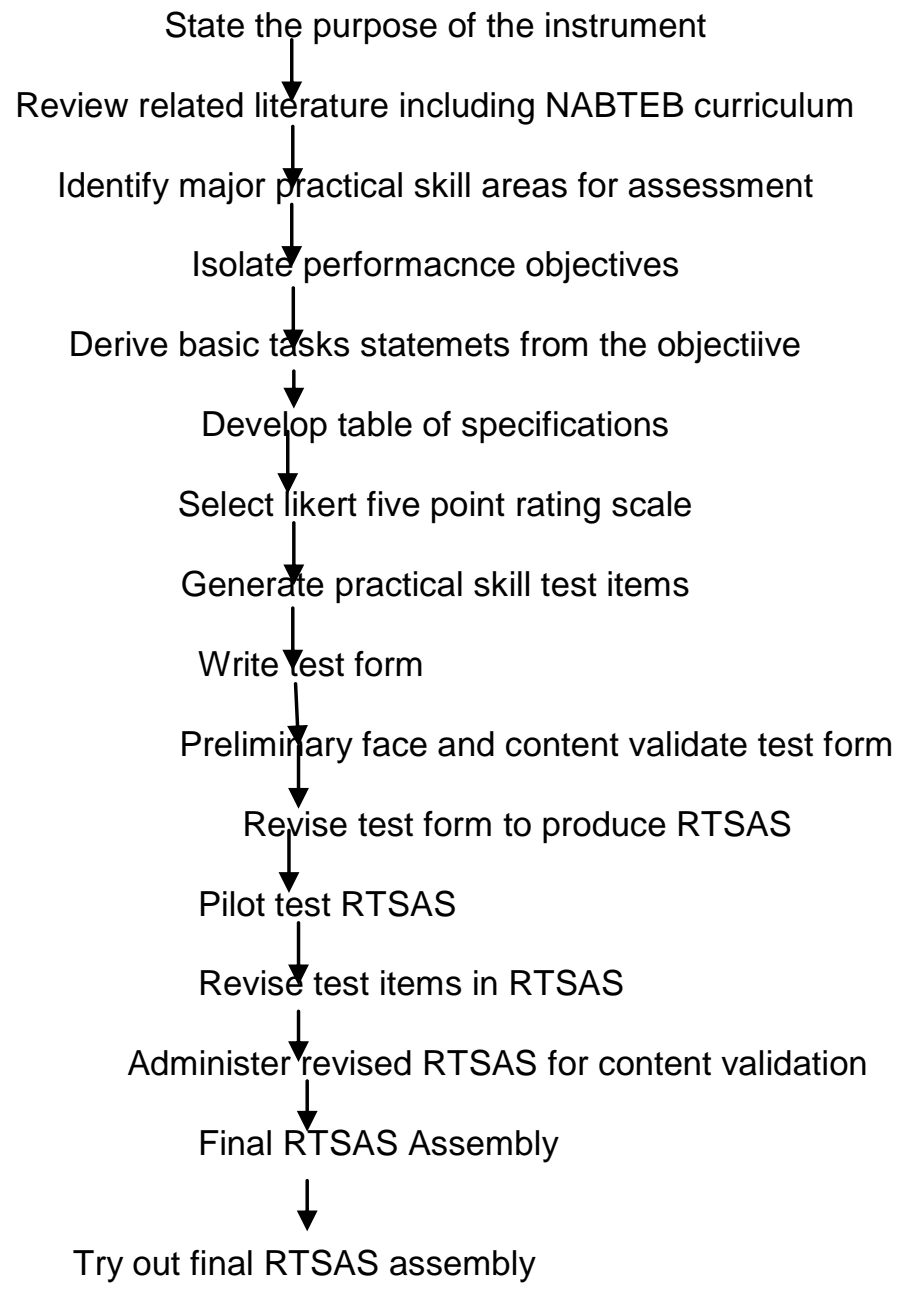

Fig 1: Flowchart for RTSAS Development

The instrument developed will assess practical skills performance of students in Radio and Television in technical colleges in Nigeria. Following a detailed review of relevant literature and NABTEB curriculum for the award of National Technical certificate (NTC) in Radio Television and Electronic works, diagnosing faults and repairs of radio and television systems, 
was identified as a major practical skills area for assessment in the NABTEB curriculum.

Next, six performance objectives relating to this major practical skills area were isolated from the curriculum. Based on the critical review of relevant literature, these objectives were transformed into six basic task statements. A table of specifications of two-way grids was developed; the horizontal axis lists the six basic tasks statement (content areas) and the vertical axis lists the six levels of psychomotor domain of Padelford (1984). This was with the view to ensuring that all basic task areas and various levels of behavioural objectives were adequately covered. The six basic task areas were further analyzed based on available literature, to generate 78 practical skill items or specific tasks statements which were matched with the appropriate cells on the table of specifications. At this stage, the test items were written by expressing the extent of appropriateness or otherwise of performing each of 78 specific task statements, employing the Likert five point rating scale format with response options in the order of Highly Appropriate, Appropriate, Moderately Appropriate, Inappropriate and Highly Inappropriate, with assigned values of 5, 4, 3, 2 and 1 respectively, to form the initial copy of the assessment instrument.

Preliminary face and content validation of the draft instrument was carried out by recruiting a panel of seven experts; three lecturers in Technical Education, two lecturers in Measurement and Evaluation; and two Radio and Television technical teachers. Following the comments of these experts, a final instrument consisting of six basic task areas and 76 practical skill items which was named as the "Radio and Television Skill Assessment Scale" (RTSAS) was assembled. A pilot testing of the draft RTSAS was carried out on 15 final year students who were not part of the study sample for the purpose of estimating initial reliability. The internal consistency reliability of the instrument was determined by calculating Cronbach's alpha reliability coefficient which yielded overall instrument reliability of 0.86 . This value exceeded Nunnally's criterion of 0.7 accepted for statistical consideration (Nunnally, 1978). The choice of Cronbach's alpha method in determining the reliability coefficient was informed by the fact that the instrument had lots of test items and in clusters (Trochim, 2006).

Based on the results of the pilot study, the draft RTSAS was revised in wordings to produce the test form for further validation. In order to determine the tasks and practical skills appropriate for inclusion in the final test, copies of the preliminary validated RTSAS was administered to 41 technical teachers in radio, television and electronic works department of the 20 technical colleges that run NABTEB programme across the South - South states of Nigeria. The instrument was arranged in two parts: I and II. Part I sought demographic information about the respondents while part II had 76 items dealing with skill in diagnosing faults and repairs of electronic circuits. A five point scale of Highly Appropriate (HA), Appropriate (A), Moderately Appropriate (MA), Inappropriate (IA), Highly Inappropriate $(\mathrm{HI})$, were written against each of the practical skill statements with a corresponding assigned values of $5,4,3,2$, and 1 respectively.

All the 41 draft copies of the RTSAS administered and returned were found to be valid and therefore used in the study. None of the six basic task and 76 practical skill items was dropped as they were rated above "Moderately Appropriate". The result of this exercise was used to assembly the final form of RSTAS with new rating options of Excellent, Very Good, Good, Fair and Poor, with assigned values of $5,4,3,2$ and 1 respectively. This final version of RSTAS was tried out on 38 RTV students from one technical college each in Bayelsa and Rivers States. The internal consistency reliability of the instrument was ascertained using the Cronbach's alpha method to obtain the overall reliability coefficient of 0.95 .

Data for answering the research question was analyzed using the mean and standard deviation. In order to select the appropriate tasks and practical skills for inclusion in the radio and television performance tests (RTSAS), a mean cut-off of 3.00 , which is moderately appropriate was chosen. Therefore, any practical skill with a mean score of 3.00 and above was appropriate, while a practical skill with a mean score below 3.00 was inappropriate.

The null hypotheses one and two were tested at five percent level of significance, using One - Way Analysis of Variance (ANOVA). For testing null hypotheses, if the calculated $\mathrm{F}$-value was equal or greater than the F-Table value at five percent level of significance, the null hypotheses were rejected but if the F-calculated was less than F-Table value, the null hypotheses was accepted. All statistical analysis was performed with Statistical Package for Social Sciences (SPSS) statistical soft ware. 
RESULTS AND DISCUSSIONS

Research question: What practical skills are considered appropriate for inclusion in Radio and
Television Skill Assessment Scale (RTSAS) for assessing students' practical skills in fault diagnoses and repairs of radio and television systems?

Table 1. Mean Ratings of Practical Skills for Diagnosing Faults and Repairs in Radio/ Television Systems

\begin{tabular}{|c|c|c|c|c|}
\hline $\mathbf{S} / \mathbf{n}$ & $\begin{array}{l}\text { Practical skills for Localizing } \\
\text { Defective Stage(s) in Radio/ } \\
\text { Television using Signal Generator } \\
\text { and CRO }\end{array}$ & $(\bar{X})$ & SD & REMARKS \\
\hline 1. & $\begin{array}{l}\text { Identify and number all test points on } \\
\text { the schematic diagram (if any) }\end{array}$ & 4.00 & 0.89 & Appropriate \\
\hline 2. & $\begin{array}{l}\text { Press "ON" the power switch to } \\
\text { energize the signal generator (power } \\
\text { light indicating diode comes on) }\end{array}$ & 4.36 & 0.69 & Appropriate \\
\hline 3. & $\begin{array}{l}\text { Select the desired signal range ( } \mathrm{RF} \text {, } \\
\text { Modulated RF or AF signal) }\end{array}$ & 4.48 & 0.59 & Appropriate \\
\hline 4. & $\begin{array}{l}\text { Select the appropriate type of signal } \\
\text { waveform }\end{array}$ & 4.31 & 0.47 & Appropriate \\
\hline 5. & $\begin{array}{l}\text { Set the frequency of the selected } \\
\text { signal to a desired value }\end{array}$ & 4.56 & 0.56 & Appropriate \\
\hline 6. & $\begin{array}{l}\text { Set the amplitude of the signal to the } \\
\text { desired value }\end{array}$ & 4.17 & 0.86 & Appropriate \\
\hline 7. & Switch on the Radio / TV set & 4.04 & 0.83 & Appropriate \\
\hline 8. & $\begin{array}{l}\text { Connect the two test leads of the signal } \\
\text { generator to the input circuit or stage } \\
\text { under test (ground terminal of the signal } \\
\text { generator to the nearest chassis of the } \\
\text { Radio / TV and live lead to the test } \\
\text { point) }\end{array}$ & 4.36 & 0.82 & Appropriate \\
\hline 9. & $\begin{array}{l}\text { Switch on the CRO from the power } \\
\text { switch (power light indicating diode } \\
\text { comes on) }\end{array}$ & 4.21 & 0.72 & Appropriate \\
\hline 10. & $\begin{array}{l}\text { Set the } \mathrm{AC} / \mathrm{DC} / \mathrm{GND} \text { switch to } \mathrm{AC} \\
\text { position }\end{array}$ & 4.41 & 0.63 & Appropriate \\
\hline 11. & $\begin{array}{l}\text { Set the sweep frequency switch to the } \\
\text { lowest range }\end{array}$ & 4.19 & 0.55 & Appropriate \\
\hline 12. & Set the SYNC switch to "internal sync" & 4.04 & 0.71 & Appropriate \\
\hline 13. & Set the SYNC to AUTO & 3.95 & 0.77 & Appropriate \\
\hline 14. & $\begin{array}{l}\text { Adjust the vertical position (up/down) } \\
\text { and horizontal position (left/right) } \\
\text { controls of the scope to put the trace } \\
\text { (beam) at the centre of the screen of } \\
\text { the scope }\end{array}$ & 4.02 & 0.61 & Appropriate \\
\hline 15. & $\begin{array}{l}\text { Set } \mathrm{V} \text {-gain (Y-amplitude) to a moderate } \\
\text { value (about } 5 \mathrm{v} / \mathrm{cm} \text { ) }\end{array}$ & 4.17 & 0.54 & Appropriate \\
\hline 16. & $\begin{array}{l}\text { Set } \mathrm{H} \text {-gain (time base) to a moderate } \\
\text { speed (about } 10 \mathrm{~ms} / \mathrm{cm} \text { ) }\end{array}$ & 4.09 & 0.73 & Appropriate \\
\hline 17. & $\begin{array}{l}\text { Adjust INTENSITY (brightness) and } \\
\text { FOCUS (sharpness) to give a bright } \\
\text { and sharp trace }\end{array}$ & 4.07 & 0.56 & Appropriate \\
\hline 18. & $\begin{array}{l}\text { Connect the two test leads of the scope } \\
\text { to the circuit under test (ground test } \\
\text { lead of the scope to nearest ground } \\
\text { point of the test circuit on the board and } \\
\text { live test lead to the output of the circuit } \\
\text { or stage under test) }\end{array}$ & 3.97 & 0.56 & Appropriate \\
\hline
\end{tabular}


Am. J. Sci. Ind. Res., 2012, 3(3): 181-190

\begin{tabular}{|c|c|c|c|c|}
\hline 19. & $\begin{array}{l}\text { Observe trace pattern on the screen (if } \\
\text { signal disappears, it is an indication of } \\
\text { faulty circuit or stage. Where signal } \\
\text { remains, continue with the following } \\
\text { steps) }\end{array}$ & 4.29 & 0.60 & Appropriate \\
\hline 20. & $\begin{array}{l}\text { Adjust FINE FREQ control on CRO until } \\
\text { one cycle or two waveform pattern } \\
\text { appears stationary on the screen }\end{array}$ & 4.34 & 0.61 & Appropriate \\
\hline 21. & $\begin{array}{l}\text { Adjusts the V- gain (volt/cm) switch to } \\
\text { measure the amplitude of the displayed } \\
\text { signal (choose a setting so that trace } \\
\text { occupies at least half the screen) }\end{array}$ & 4.21 & 0.41 & Appropriate \\
\hline 22. & $\begin{array}{l}\text { Adjust the H-gain (time base) switch to } \\
\text { produce the desired signal width on the } \\
\text { screen }\end{array}$ & 3.97 & 0.35 & Appropriate \\
\hline 23. & $\begin{array}{l}\text { Measure the frequency of the signal } \\
\text { waveform being measured }\end{array}$ & 4.21 & 0.52 & Appropriate \\
\hline 24. & Identify the faulty stages of the circuit & 4.07 & 0.68 & Appropriate \\
\hline 25. & Handle equipment carefully & 3.95 & 0.71 & Appropriate \\
\hline 26. & Handle the circuit board carefully & 3.82 & 0.66 & Appropriate \\
\hline 27. & Observe safety rules during the task & 3.78 & 0.68 & Appropriate \\
\hline \multirow[t]{2}{*}{28.} & $\begin{array}{l}\text { Carry out the tasks within stipulated } \\
\text { time }\end{array}$ & 3.75 & 0.76 & Appropriate \\
\hline & $\begin{array}{l}\text { Practical Skills in Analyzing } \\
\text { Component Level Defect(s) using } \\
\text { Multi-meter }\end{array}$ & & & \\
\hline 29. & $\begin{array}{l}\text { Identify the dc voltage point on the } \\
\text { circuit board }\end{array}$ & 4.31 & 0.64 & Appropriate \\
\hline 30. & $\begin{array}{l}\text { Insert the red test lead into the "+" jack } \\
\text { and the black test lead into the "-COM" } \\
\text { jack of the meter }\end{array}$ & 4.29 & 0.74 & Appropriate \\
\hline 31. & $\begin{array}{l}\text { Set the meter scale indicator needle to } \\
\text { zero position (if analog meter is used) }\end{array}$ & 4.26 & 0.50 & Appropriate \\
\hline 32. & $\begin{array}{l}\text { Set the range selector switch of the } \\
\text { meter to a desired DC voltage range } \\
\text { position if voltage value is known }\end{array}$ & 4.34 & 0.48 & Appropriate \\
\hline 33. & $\begin{array}{l}\text { Set the range selector switch of the } \\
\text { meter to highest DC voltage range } \\
\text { position and work down if voltage value } \\
\text { is unknown }\end{array}$ & 4.04 & 0.49 & Appropriate \\
\hline 34. & $\begin{array}{l}\text { Connect the two test leads of the meter } \\
\text { to } D C \text { voltage points of the circuit under } \\
\text { test (red lead to the positive polarity and } \\
\text { black lead to negative) }\end{array}$ & 4.31 & 0.47 & Appropriate \\
\hline 35. & $\begin{array}{l}\text { Read the DC voltage scale in } \\
\text { accordance with the provided reference } \\
\text { Table, if analog meter is used. }\end{array}$ & 4.43 & 0.50 & Appropriate \\
\hline 36. & $\begin{array}{l}\text { If digital meter is used, read the value of } \\
\text { the DC voltage on the digital display of } \\
\text { the meter (the value recorded should be } \\
\text { equal to value on the digital display } \\
\text { multiplied by range setting) }\end{array}$ & 4.46 & 0.63 & Appropriate \\
\hline 37. & Identify the suspected component & 4.24 & 0.48 & Appropriate \\
\hline 38. & Handle the meter skillfully & 4.00 & 0.44 & Appropriate \\
\hline 39. & Handle the PCB skillfully & 3.65 & 0.48 & Appropriate \\
\hline 40. & Observe safety rules during the task & 3.78 & 0.47 & Appropriate \\
\hline 41. & Complete tasks within stipulated time & 3.34 & 0.65 & Appropriate \\
\hline
\end{tabular}


Am. J. Sci. Ind. Res., 2012, 3(3): 181-190

\begin{tabular}{|c|c|c|c|c|}
\hline & $\begin{array}{l}\text { Practical Skills in Removing } \\
\text { Components Using Soldering Iron } \\
\text { and Lead Sucker }\end{array}$ & & & \\
\hline 42. & $\begin{array}{l}\text { Apply soldering iron to the component } \\
\text { lead for a stipulated time }\end{array}$ & 3.75 & 0.66 & Appropriate \\
\hline 43. & $\begin{array}{l}\text { Suck out molten lead using lead } \\
\text { sucker, then brush out }\end{array}$ & 4.31 & 0.52 & Appropriate \\
\hline 44. & $\begin{array}{l}\text { Remove component from the PCB } \\
\text { without damage }\end{array}$ & 4.24 & 0.82 & Appropriate \\
\hline 45. & The soldered joints are free from dirt & 4.14 & 0.91 & Appropriate \\
\hline 46. & Conduction tracks are not damaged & 4.26 & 0.63 & Appropriate \\
\hline 47. & Handle soldering iron skillfully & 4.09 & 0.62 & Appropriate \\
\hline 48 & Handle PCB skillfully & 3.97 & 0.41 & Appropriate \\
\hline 49 & $\begin{array}{l}\text { Observe safety measures relating to } \\
\text { dis-soldered }\end{array}$ & 4.07 & 0.75 & Appropriate \\
\hline 50 & $\begin{array}{l}\text { Handle component by their correct art } \\
\text { while removing }\end{array}$ & 3.73 & 0.75 & Appropriate \\
\hline 51 & Complete task with stipulated time & 3.73 & 0.70 & Appropriate \\
\hline & $\begin{array}{l}\text { Practical Skills in Testing to Detect } \\
\text { Defective Component(s) Using Multi- } \\
\text { Meter }\end{array}$ & & & \\
\hline 52 & $\begin{array}{l}\text { Insert the red test lead into the "+" jack } \\
\text { and the black test lead into the "-COM" } \\
\text { jack of the meter }\end{array}$ & 4.26 & 0.54 & Appropriate \\
\hline 53 & $\begin{array}{l}\text { Set the meter's range selector switch to } \\
\text { measure the required resistance }\end{array}$ & 4.09 & 0.70 & Appropriate \\
\hline 54 & $\begin{array}{l}\text { Short the test leads and set the meter } \\
\text { scale indicator needle to zero position } \\
\text { (if analog meter is used) }\end{array}$ & 4.34 & 0.48 & Appropriate \\
\hline 55 & $\begin{array}{l}\text { Connect the two test leads of the meter } \\
\text { to the terminals of the resistors being } \\
\text { measured (no voltage across circuit } \\
\text { under test) }\end{array}$ & 4.53 & 0.63 & Appropriate \\
\hline 56 & $\begin{array}{l}\text { Read the ohms scale in accordance } \\
\text { with the provided reference Table (if } \\
\text { analog meter is used) }\end{array}$ & 4.43 & 0.71 & Appropriate \\
\hline 57 & $\begin{array}{l}\text { If digital meter is used, obtain the } \\
\text { correct reading of the resistance from } \\
\text { the meter's digital display (the value } \\
\text { recorded should be equal to the value } \\
\text { of digital display multiplied by range } \\
\text { setting). }\end{array}$ & 4.42 & 0.50 & Appropriate \\
\hline 58 & Identify the nature of the fault & 4.24 & 0.43 & Appropriate \\
\hline 59 & $\begin{array}{l}\text { Observe safety rules while testing } \\
\text { component }\end{array}$ & 3.95 & 0.74 & Appropriate \\
\hline 60 & $\begin{array}{l}\text { Handle components properly while } \\
\text { testing }\end{array}$ & 3.56 & 0.50 & Appropriate \\
\hline \multirow[t]{2}{*}{61} & $\begin{array}{l}\text { Carried out the task within stipulated } \\
\text { time }\end{array}$ & 3.75 & 0.83 & Appropriate \\
\hline & $\begin{array}{l}\text { Practical Skills in Repairs and } \\
\text { Assembly using Soldering Iron and } \\
\text { Multi-Meter }\end{array}$ & & & \\
\hline
\end{tabular}


Am. J. Sci. Ind. Res., 2012, 3(3): 181-190

\begin{tabular}{|c|c|c|c|c|}
\hline & & & & \\
\hline 62 & $\begin{array}{l}\text { Select component of correct } \\
\text { specification }\end{array}$ & 4.46 & 0.74 & Appropriate \\
\hline 63 & $\begin{array}{l}\text { Verify the condition of the component } \\
\text { before pulling back }\end{array}$ & 4.46 & 0.50 & Appropriate \\
\hline 64 & Fix back components into PCB correctly & 4.00 & 0.22 & Appropriate \\
\hline 65 & $\begin{array}{l}\text { Component leads are visible from the } \\
\text { other side of the PCB }\end{array}$ & 4.92 & 0.44 & Appropriate \\
\hline 66 & $\begin{array}{l}\text { Apply soldering iron for only a stipulated } \\
\text { time }\end{array}$ & 4.09 & 0.86 & Appropriate \\
\hline 67 & $\begin{array}{l}\text { Apply sufficient flux to point(s) being } \\
\text { soldered }\end{array}$ & 4.00 & 0.67 & Appropriate \\
\hline 68 & $\begin{array}{l}\text { Soldered point(s) are firm, bright and } \\
\text { shinny }\end{array}$ & 3.92 & 0.64 & Appropriate \\
\hline 69 & $\begin{array}{l}\text { Observed safety rules relating to } \\
\text { soldering of components }\end{array}$ & 3.80 & 0.84 & Appropriate \\
\hline 70 & Handle PCB skillfully & 3.46 & 0.71 & Appropriate \\
\hline & $\begin{array}{l}\text { Practical Skills in Testing } \\
\text { Functionality of Repaired Radio and } \\
\text { Television System }\end{array}$ & & & \\
\hline 71 & Appropriate tests are carried out & 4.85 & 0.35 & Appropriate \\
\hline 72 & All functions operated well & 4.04 & 0.31 & Appropriate \\
\hline 73 & No open circuit identified & 4.02 & 0.27 & Appropriate \\
\hline 74 & No short circuit identified & 3.92 & 0.41 & Appropriate \\
\hline 75 & System working and certified okay & 3.95 & 0.77 & Appropriate \\
\hline 76 & Finish task within stipulated time & 3.65 & 0.61 & Appropriate \\
\hline
\end{tabular}

Results from Table1 revealed that the mean scores of respondents ranged from 3.34 to 4.92. All the items had their mean scores above the cut-off point of 3.00 , signifying that the respondents considered all the 76 items as being appropriate practical skills for inclusion in the RTSAS. The standard deviation (SD) of the items ranged from 0.22 to 0.89 , implying that the respondents were very close in their ratings.
Hypothesis 1: There are no significant differences among three groups of trained technical teachers regarding the appropriateness of practical skills for inclusion in radio and television skill assessment scale (RTSAS) $(P<0.05)$.

Table 2. ANOVA of Three Groups of Trained Teachers' Ratings of Practical Skills for Inclusion in RTSAS.

\begin{tabular}{|c|c|c|c|c|c|c|}
\hline $\begin{array}{l}\text { Source of } \\
\text { Variation }\end{array}$ & $\begin{array}{c}\text { Sum of } \\
\text { squares }\end{array}$ & Df & $\begin{array}{l}\text { Mean } \\
\text { Square }\end{array}$ & f-cal & f-tab & Remark \\
\hline Between Groups & 27250.439 & 2 & 13625.220 & \multirow{3}{*}{3.091} & \multirow{3}{*}{3.32} & \multirow{3}{*}{${ }^{*}$ Accepteo } \\
\hline Within Groups & 167504.00 & 38 & 4408.000 & & & \\
\hline Total & 194754.44 & 40 & & & & \\
\hline
\end{tabular}

$\mathrm{n}=41 \mathrm{p}<0.05, \mathrm{df}=(2,38),{ }^{*}$ Accepted

Table 2 showed that there are no significant differences across the three groups of trained technical teachers regarding the appropriateness of practical skills for inclusion in RTSAS. This is evident from the table since the f-calculated value of 3.091 is less than the f-tabulated value of 3.32 at five percent level of significance. The first hypothesis was therefore accepted.

Hypothesis 2: There are no significant differences among three groups of experienced technical teachers regarding the appropriateness of practical 
Am. J. Sci. Ind. Res., 2012, 3(3): 181-190

skills for inclusion in radio and television skill assessment scale (RTSAS) $(P<0.05)$.

Table 3. ANOVA of Three Groups of Experienced Teachers' Ratings of Practical Skills for Inclusion in RTSAS.

\begin{tabular}{|l|c|c|c|c|c|c|}
\hline $\begin{array}{l}\text { source of } \\
\text { variation }\end{array}$ & $\begin{array}{l}\text { Sum of } \\
\text { squires }\end{array}$ & Df & $\begin{array}{c}\text { Mean } \\
\text { Square }\end{array}$ & F-cal & F-tab & Remark \\
\cline { 1 - 5 } Between Groups & 18026.969 & 2 & 9014.485 & & \multirow{2}{*}{ *Accepted } \\
\cline { 1 - 5 } Within Groups & 176725.47 & 38 & 4650.670 & & \\
\hline Total & 19475.44 & 40 & & & \\
\hline
\end{tabular}

$\mathrm{n}=41 \mathrm{p}<0.05, \mathrm{df}=(2,38){ }^{*}$ Accepted

Table 3 indicated that F-calculated value of 1.938 is les than F-Table value of 3.32 at five percent level of significance. This implies that there are no significant differences among the three groups of experienced technical teachers regarding the appropriateness of practical skills for inclusion RTSAS. The second hypothesis therefore was accepted.

\section{DISCUSSIONS}

The main contribution of this study was the successful development of a valid and reliable test instrument to assess practical skills of students in radio and television in technical colleges. The result related to the research question indicated that all the 76 practical skills were considered appropriate for inclusion in the radio and television skill assessment scale (RTSAS). This signifies that the teachers of radio and television in technical colleges considered the 76 skill activities as appropriate for use in assessing students' performance in practical areas of radio and television systems. This finding is consistent with Garba (1993) and lji (2007) regarding the fact that all the items of the test instruments they developed were considered by the respondents as appropriate for use in assessing students' performance.

The non-significance differences among the various groups of teachers that participated in the instrument validation are further evidence of the instrument's validity. The analysis of data relating to the first null hypothesis revealed that there were no significant differences among three groups of trained technical teachers (FTC / TTC / NCE; B.Sc. / HND / PGDTE; M.Sc. / PhD) regarding the skills for inclusion in RTSAS. This entails that qualification was not a significant factor in deciding which practical skill should be selected for the RTSAS instrument. This result suggests similar ratings in appropriateness of skills by all the teachers and contradicts the findings of Chiejile (2006) who found that FTC teachers rated the electrical installation tasks higher than other groups.

In respect of the second null hypothesis, it was found that there were no significant differences among the three groups of experienced technical teachers (below 5 years; 5 to 10 years; above 10 years) regarding the appropriateness of practical skills for inclusion in RTSAS. This is an indication that years of experience was not a determining factor in selecting practical skills appropriate for inclusion in the RTSAS instrument, suggesting similar ratings in appropriateness of practical skills by all teachers of various years of experience.

\section{CONCLUSION}

Preliminary data obtained in this study indicate that the "Radio and Television Skill Assessment Scale" (RTSAS) is a valid and reliable rating instrument that could be used in assessing students' practical skills performance in diagnosing faults and repairs in radio and television systems in technical colleges. Some educational implications are derived from the findings of this study. First, it is expected that teachers of radio and television may now be able to use an objective, comprehensive and systematic instrument to effectively assess students' performance in practical works. In so doing, the teachers will be able to show proof of the scores and grades that they award. Second, it is believed that students' performance in radio and television trade especially the practical aspect will be improved.

\section{RECOMMENDATIONS}

Based on the findings of this study, the following recommendations are made: 
1. Radio and television teachers in technical colleges and similar skill acquisition institutions should be made to be aware and learn to use the RTSAS for assessing practical works in radio and television trade.

2. National Business and Technical Examination Board (NABTEB) and similar examination bodies could consider using the RTSAS in assessing students' performance at NTC level and other examinations at post- primary level.

\section{REFERENCES}

Benson, J. and Clark, F. (1982). A guide for instrument development and validation. The American Journal of Occupational Therapy. 36(12), 789 - 800. Retrieved October 13, from http://www.Scinf.umontreal.

Bukar B. (1995). Development of an instrument for evaluating practical projects in electronics. Unpublished master's thesis, University of Nigeria, Nsukka, Nigeria.

Bukar, B. (2006). Development and validation of Laboratory-based tests for assessing practical skills of HND students in electronic maintenance and repair. Unpublished doctoral dissertation, University of Nigeria, Nsukka, Nigeria.

Chiejile, L. C. (2006). Development and validation of a test instrument for assessing students' practical performance in electrical installations. Unpublished doctoral dissertation, Nnamdi Azikiwe University, Awka, Nigeria.

Cluzeau, F. (2002). Development and validation of an international appraisal instrument for assessing the quality of clinical practice guidelines: the AGREE project. Retrieved October 15, 2010 from http://gshc. bmj.com/content/12/1/18 fall

Federal Republic of Nigeria (2004). National policy on education $\left(4^{\text {th }}\right.$ ed.). Lagos: NERDC Press.

Garba, L. N. (1993). Development of an instrument for evaluating practical project in woodwork. Unpublished doctoral dissertation, University of Nigeria, Nsukka, Nigeria.

Gay, L. R. (1996). Educational research .competences, for analysis and application. ( $5^{\text {th }}$ Ed.). Merrill, NJ: Prentice Hall.

lji, C. O. (2007). An instrument for evaluating higher degree thesis in education. Journal of Research in Education. 4 (2), $76-80$.

Khan, M. S. (2007). School evaluation. New Delhi: A.P.H. Publishing Corporation.

Mansell, J. (2002). General issues about assessment of competence. Assessment and Evaluation in Higher Education Journal 19 (1) 3-16.
National Business and Technical Examinations Board (NABTEB). (2004). Syllabus for engineering trades for the national technical certificate examinations. Benin City: Yuwa Printing Press.

Nunnally , J. C. (1978). Psychometric theory. New York: McGraw-Hill.

Ojoko, S. S. (2000). Measurement and evaluation in teacher education. Owerri: Springfield Publishers.

Okeke, B. C. (2004). Standardization of an instrument for assessing pracing work technology in technical colleges. Journal of Vocational and Adult Education 3(1), 42-52.

Okwelle, P. C. (2011). Development and validation of instrument for assessing practical skills in radio and television systems in technical colleges. Unpublished doctoral dissertation, Nnamdi Azikiwe University, Awka, Anambra State, Nigeria..

Okwelle, P. C. (2003). Construction of valid evaluation instruments in technology education. Journal of Technical and Science Education. 12 (1\&2) $72-81$.

Olaitan, S. O. and Ali, A. ( 2000). The making of a curriculum (theory, process, product and evaluation). Onitsha: Cape Publishers International Limited.

Orion, N., Hofstain, A.; Tamir, P.\& Giddings, G. J. (1997). Development and validation of an instrument for assessing the learning environment of outdoor science activities. Retrieved October 15, 2010 from http://stwww.weizman.ac.il/g-earth/geogroup/whole _ articles/a7-whole.pdf.

Padelford, H. E. (1984). Acquiring psychomotor skills. Journal of Epsilon P Tau. X(2), 35-39.

Samarakkody, D. C., Fernando, D. N., Perera, H., McClure, R. J; \& Silva, H. D. (2010). The child behavior assessment instrument: Development and validation of a measure to screen for externalizing child behavioural problems in community setting. International Journal of mental health systems. 4,13. Retrieved October 15, 2010 from http://www.ijmhs.com/content/4/1/13.

Trochim, W. M. K. (2006). Types of reliability. Retrieved December 10, 2009 from http://www.social research methods.net/kb/reltypes.plp.

Wiersma, W. and Jurs, S. G. (1990). Educational measurement and testing. U.S.A: Allyn and Bacon, Inc.

Wolansky, W. (1988). Evaluation tools in valid test construction. In R. O. Ohuche (Ed.). International Journal of Educational Research, 2: 77 - 92.

Yalams, S. M. (2001). Development and validation of metal work process evaluation scheme. Unpublished doctoral dissertation, University of Nigeria, Nsukka, Nigeria 